\title{
The Effect of Institutional Ownership on Firm Performance: Evidence from Jordanian Listed Firms
}

\author{
Dana AL-Najjar ${ }^{1}$ \\ ${ }^{1}$ Finance and Banking Department, Applied Science Private University, Jordan \\ Correspondence: Dana AL-Najjar, Finance and Banking Department, Applied Science Private University, P.O Box \\ 166, Postal code 11931, Amman, Jordan. Tel: 962-777-476-164. E-mail: dananajjar_2002@yahoo.com
}

Received: September 29, 2015

Accepted: November 9, 2015 Online Published: November 25, 2015

doi:10.5539/ijef.v7n12p97

URL: http://dx.doi.org/10.5539/ijef.v7n12p97

\begin{abstract}
Last decade witnessed successive corporate scandals for various firms that points to a failure of corporate control. Expertize and interested parties all over the world proposed to focus on monitoring the management decisions to reduce such failure in firms. Therefore, the structure of ownership became more and more as an important issue to increase both efficiency and effectiveness of management decisions. This study seeks to investigate whether institutional ownership affects the firm's performance for one of the emerging markets; Jordan. Firm's performance is measured through applying two accounting measures Return on Assets (ROA) and Return on Equity (ROE), with 6 explanatory variables. Our sample is unique and contains 82 non-financial Jordanian firms listed at Amman Stock Exchange (ASE) for the period of 2005-2013, by applying panel data regression analysis. It depends on building three OLS models: Pooled, Fixed Effects Model and Random Effects Model. In addition, a test for Breusch and Pagan Lagrangian multiplier (LM), and Hausamn test to choose among the three models which model is most suitable for our data. A main finding of the panel data analysis is that; fixed effect regression is the most convenient model. As a result, there is no strong evidence that there is a relationship between both institutional ownership and firm performance for Jordanian listed firms. This conclusion can be due to the fact that institutional ownership has its own pros and cons, therefore, their existence and influence could affect materially the types and risk level of investment decisions taken by the management which in return will affect the firm's performance as a whole.
\end{abstract}

Keywords: emerging markets, firm performance, institutional ownership, Jordan

\section{Introduction}

The spate of corporate scandals in the last ten years points to a failure of corporate control. Expertize all over the world proposed to focus on monitoring the management decisions to reduce such failure in firms. Therefore, the structure of ownership became more and more as an important issue to increase both efficiency and effectiveness of management decisions. Furthermore, institutional ownership in public firms has emerged as being one of the important groups in the capital structure due to the argument that institutional investors can achieve being corporate monitors; caused by having both expertise and resources that facilitate positively monitoring management decisions sufficiently, which in return will affect the firm performance as a whole (Grossman \& Hart, 1980; Joher et al., 2006). The literature on both developed and emerging countries indicates that highly concentrated ownership is more wide spread in the ownership structure of the firms (Sheifler \& Vishny, 1997; La porta et al., 1999).

The causality relationship between ownership and performance has been discussed traditionally by agency theory. So far, it has not been easy on scholars to answer the question regarding whether there is an important effect between these two variables or not. thus findings and opinions by scholars, academic researches' and managers regarding the main role of ownership structure on performance in firms have been controversy, hence it enhanced the focus of empirical researchers worldwide to provide a considerable body of research on the role of institutional investors on firm performance especially in developed countries such as Japan, Europe and the United States of America. The main aim of those studies was due to examining which logical possible explanation and relationship can be more probable for the selected sample and country.

As for nowadays corporate governance has took the lead to explore many aspects reflecting the impact of ownership structure on firm's performance. Regarding the corporate governance there is no agreed on definition, 
but the most authoritative functional definition available is provided by Organization for Economic Cooperation and Development (OECD) which states that, it is: "Procedures and processes according to which an organization is directed and controlled".

Moreover, the first pioneering empirical tests on ownership- performance and ownership concentration is credited to Berle and Means (1932) who investigated the hypothesis of negative correlation between both the diffuseness of shareholdings and firm performance, but the study of Jensen and Meckling (1976) is the one hence showing that equity ownerships held by different groups have various effects on the firm performance, also it provided solid ground on the positive relationship between both the institutional ownership and firm's performance.

Most of the existing studies regarding the role of ownership structure on firm performance are from mature, developed countries with high investor protection, and hence it has been recently a target by researchers in emerging countries to explore the availability of a probable relationship between institutional ownership and firm performance with limited evidence of such relation in Jordan. Our study thus aims to bridge the gap in the literature by investigating this relationship in comprehensive sample of Jordanian listed firms as well as using the most updated period. Hence, our aim is to add to the empirical evidence concerning the exploration of the relationship between institutional ownership and firm performance in emerging countries by examining data for non-financial Jordanian firms' listed at Amman Stock Exchange.

The reminder of this paper is organized as follows section 2 explains literature review, Section 3 summarizes major points regarding institutional ownership and hypothesis development and study models, Section 4 presents the data and methodology, and Section 6 concludes.

\section{Literature Review}

The review of literature for the impact of institutional ownership on the firm's performance shows no agreed relationship, and delivers strong debate on the topic among various studies in different countries from developed to developing countries. As mentioned earlier, this work can be traced back to the pioneering study of Berle and Means (1932), that discussed the "black box" theory of the firm which considers firm to be as a box that transforms inputs to outputs, also it argued that the separation of ownership and control of modern companies is expected to decrease management incentives to maximize corporate efficiency.

Moreover, The studies of Pound's (1988), Brickley, Lease, and Smith (1988); and Kochhar and David (1996) investigated the various dimensions of institutional ownership and their effect on firm performance by classifying the institutional ownership into two groups; pressure-resistant and pressure sensitive institutional investors, their main findings were that; the relationship between pressure sensitive institutional investor and firm performance is negative, caused by the likely business relationship between both institutional investor and the firms they hold equity in, hence, the opposite hold true for pressure-resistant institutional ownership.

More studies provided by Gilson and Roe (1993), and Roe (1994) argued that the relationship between institutional ownership and firm's performance varies among other things that are related to industry and country. In addition, Shleifer and Vishny (1986) findings support the stronger effect of monitoring managers by large shareholders especially institutional investors rather than the firm's board of directors who have either little or no ownership in the firm. Moreover, the strong effect can be referred to the fact that large institutional investors have the opportunity, ability to monitor, discipline, resources, and influence managers. For McConnell and Servaes (1990), Nesbitt (1994), Smith(1996) and Del Guercio and Hawkins (1999) all their findings provided more evidence that supports the hypothesis stating that; institutional investor monitoring enhances the managers focus on the firm performance and less on opportunistic or self-serving behavior. On the other hand, Maug (1998) noted that institutions' use of their ability to influence corporate decisions is partially a function of the size of their shareholdings. If the firm has high institutional investor shareholdings, then shares are expected to be less marketable and are thus most probably held for longer periods. In this case, there is a greater incentive to monitor a firm's management.

In paper of Dematz and Villolonga (2001); the endogeneity between performance and institutional ownership issue has been investigated, their main results was that ownership and performance affect each other in various ways. Another study in the same year for Hossain et al. (2001) regarding stock held by the top 20 shareholders in New Zealand, its main results indicated that the firms which are highly concentrated consequently induces better monitoring and reduces the potential for entrenchment of managers. Also, Healy (2003) found institutional ownership in New Zealand counts for $69 \%$, and suggests that firm's with higher institutional ownership implies greater monitoring. 
Besides studying the factors that affect performance, some studies investigated the effect on reducing agency cost such as Hartzell and Starks (2003); in which they reported that the relationship between block holders' ownership and performance sensitivity of managerial compensation is positive; thus, mitigating the agency problems between both the shareholders and managers can be accomplished through block holders' ownership monitoring that tends to be complementary toward the incentive compensation systems.

More proof of the existence of relationship was provided by both Cornett et al. (2007), and Chen et al. (2008) who examined the impact of institutional ownership on corporate operating performance; the results presented a confirmation to a relationship between institutional investors and operating cash flow returns, also a positive relationship between institutional ownership and firm performance values that was measured by Return on Equity.

Fazlzadeh et al. (2011) study aimed to determine the role of ownership structure on firm performance for a sample of 137 listed firms at Tehran stock exchange within the period from 2001-2006 by using panel data regression analysis; their main findings were that ownership concentration doesn't have any significant effect on firm performance. But on the other hand, regarding the institutional ownership it has positive significant effect on firm performance and the concentrated institutional ownership has a negative relationship with the performance. More recent studies such as; Fauzi and Locke (2012) revealed that board of directors; institutional ownership and board committees have all a positive significant effect on firm performance.

Contrary to the findings previously mentioned, the paper of Bhattacharya and Graham (2007) investigated the relationship between institutional ownership and firm performance; and found out that institutional investors with likely investment and business ties with firms have adverse (negative) effect on firm performance. Also, no substantive relationship between ownership structure and firm performance was found by Sanchez and Garcia (2007) study by using Meta-analysis technique, but it added that governance system, measurement of performance, and controls for endogeneity moderate the effect of ownership on firm performance. On the same path Lee (2008) used panel data regression analysis on South Korean firms for the period from 2000-2006, and the main findings were that firm's financial performance measured by the accounting rate of return on assets generally improves as ownership concentration increases, but regarding the effect of both foreign and institutional ownership they were found to have insignificant relationship with firm performance.

Based on the above discussion our paper, hence, adds to the literature by providing additional support of the interaction between institutional ownership and firm performance by examining data set from one of the emerging markets that is; Jordanian firms.

\section{Institutional Ownership: Hypothesis Development}

Back to the Berle and Means (1932) who argued about the presence of shareholders holding a high proportion of the firm's capital constitutes another way to mitigate the effects of the separation of ownership and control on firm value. The manager of a firm in which each shareholder holds only a small fraction of the firm's capital can engage in value reducing activities (Hu \& Izumida, 2008; Fazlzadeh et al., 2011).

Institutional investors may be defined as specialized financial institutions, which manage savings collectively on behalf of other investors toward a specific objective in terms of acceptable risk, return maximization, and maturity of claims (Davis \& Steil, 2001). However, this definition could be considered limited, as institutional investors vary significantly, both internally and externally. Thus, a wider definition, based basically on the theory of the firm, it could be that institutional investors are investment cooperation's set up to reduce transaction costs between investors, and managed in a professional approach (Bjuggren et al., 2007).

There is no doubt that the increase in institutional holdings has created the potential for financial institutions to play a greater role in corporate governance, but still until now it is not easy to give a clear answer regarding whether it is a favorable development or not. Moreover, the Financial Economists Roundtable (1998) believes in the positive phenomenon of increasing the institutional ownership in firms, therefore, they suggested three advantages. First, larger owners aligned with a higher proportion of economic benefits are more likely to perceive oversight activities as cost effective. Second, higher ownership positions can decrease the costs of coordinating management oversight activities with other owners. Third, larger institutions may find selling their large blocks of shares in firms in which its managers may not maximize shareholders value to be difficult and costly (Federal Reserve financial economic roundtable, 1998; Chen et al., 2008).

Furthermore, Belkir (2004) provided classical argument regarding the relationship between capital structure variables and corporate governance with firm performance that is; for some variables, the greater the level of the variable the better is the firm performance. Consider for instance, stock ownership by insiders and block holders 
(such as institutional ownership), they largely share wisdom about being control mechanisms in that, firms with more insider ownership and Block holders' ownership achieve a better performance.

Apart from the advantages previously mentioned, the Financial Economists Roundtable (1998) has also recognized that the incentive conflict problem can be posed by institutional ownership, which is the separation of ownership of stock in institutional portfolios from the management of those portfolios. Management may pursue their own interests, which becomes a cost to portfolio investors. For example, managers may mitigate their positive influence through building up special relationship with invested firms (Cornett et al., 2007; Chen et al., 2008).

The interest in institutional ownership whether in developed or emerging countries is reflected from the fact that they are considered to be effective owners and can be seen as a good monitoring device. Therefore, they are expected to improve the corporate efficiency by employing there resources, expertise and ability to properly monitor management's decisions regarding both investment and financial matters which in return will affect positively firm performance all in all. This study attempts to find out an answer to the following question for the Jordanian firms: Do institutional investors have an effect on the firm's performance? Based on this question the study's main hypothesis is:

$\mathrm{H}_{1}$ : Institutional ownership has a significant positive effect on firm performance.

\section{Data and Methodology}

\subsection{Sample}

The sample includes all the non-financial firms listed at Amman Stock Exchange (ASE) that satisfied all the following criteria: They had been actively trading at Amman Stock exchange for the period (2005-2013); their financial calendar year ended at $31^{\text {th }}$ of December; they had no major changes neither in their activities nor their calendar year. As a result the number of firms that fits into these criteria are (82) non-financial firms for the period from (2005-2013). It is worth noting that the data used in this study is hand collected from the annual reports.

\subsection{Methodology}

This study intends to find the effect of Institutional ownership on the financial performance for a sample of non-financial Jordanian firms listed at Amman Stock exchange, by applying panel data regression analysis.

The analysis has been done through: First, data description which includes descriptive statistics and correlation matrix for non-financial Jordanian firms; Second, panel data regression analysis approach to find the effect of Institutional ownership on the financial performance with 6 explanatory variables during the period (2005-2013).

Panel data analysis depends on building three OLS models: Pooled, Fixed Effects Model and Random Effects Model. Then a test for Breusch and Pagan Lagrangian multiplier (LM) and Hausamn test to choose among the three models which model is most suitable for our data.

The regression equation that represents our model to test the main hypothesis of the study is:

$$
\text { Financial performance }{ }_{i t}=\beta_{0}+\beta_{1} \text { Size }_{i t}+\beta_{2} F_{T A}+\beta_{3} B R_{i t}+\beta_{4} D / A+\beta_{5} I O_{i t}+\beta_{6} M B+\varepsilon_{i t}
$$

Which are: Firm Financial performance is measured through two proxies once as ROA then as ROE, percentage of institutional ownership (IO), size (S), tangibility (FTA), business Risk (BR), Debt to Asset (D/A) and marketability (MB).

\subsubsection{Data Description}

Ownership data are drawn from Jordan's Securities Depositary Center files. As for the other types of variables applied in this study, they are from the annual financial reports of the firms and the company guide prepared by Amman Stock Exchange.

Institutional ownership is measured through the percentage of shares held by institutional investors (such as banks, mutual funds, corporations and so on) over the total shares outstanding.

Two accounting measures have been selected as proxies for firm performance, Return on Assets (ROA) that has been used since Dimsetz and Lehn (1985) by many studies (Cornett et al., 2007; Lee, 2008; Fazlzadeh et al., 2011; and Wellalage et al., 2012) measured by Net income divided by total assets, the other indicator is Return on Equity (ROE) measured by Net income divided by total owners' equity.

Besides the ownership and in accordance with previous studies the explanatory factors that are expected to contribute significantly in explaining the variation in firm performance includes firm size measured by natural 
logarithm of total assets Ln (TA). Tangibility which measures the assets that are tangible because they contribute in the value of the firm, it is measured through the ratio of fixed assets (FA) divided by total assets (TA). For the business risk; it is the risk associated with expectations of a firm's future return on equity (ROE) measured by standard deviation of ROE $\left(\sigma_{\mathrm{ROE}}\right.$ it $)$. As for the improvement in performance reflected in the price increase; marketability is the suitable measure by multiplying market price per share with the number of shares outstanding. Lastly, leverage is the indicator for the extent in which the firm depends on debt financing measured by total debt divided by total assets (debt to asset ratio).

\section{Results}

\subsection{Descriptive Analysis}

Table 1 provides descriptive analysis for the variables included in the study; on average, Jordanian firms return on assets is double the return on equity but still considered low percentage, and the minimum amount is for the return on equity. For the size it is around 16, also the firms' holds around (10.6\%) of its total assets as cash and cash equivalents. In addition, it is around (31.4\%) of its total asset that are funded by creditors, finally (44.3\%) of the shares outstanding for the study's firms' are owned by institutions which is a large percentage.

Table 1. Descriptive analysis

\begin{tabular}{lcccc}
\hline Variable & Mean & Std. Dev. & Min & Max \\
\hline ROA & .0345 & .1043 & -.4990 & .5565 \\
ROE & .0114 & .2406 & -3.189 & .7815 \\
Size & 16.62 & 2.383 & 0 & 20.97 \\
Tangibility & 10.80 & 68.08 & 0 & 631.7 \\
Business risk & .1293 & .1702 & .0071 & 1.167 \\
D/A & .3141 & .2260 & 0 & .99 \\
Institutional ownership & .4432 & .2426 & 0 & 1 \\
Marketability & 1.169 & .8743 & 0 & 5.701 \\
\hline
\end{tabular}

In order to detect the multicollinarity problem that may exist between the variables it is important to review the correlation between selected variables. Table 2 presents the correlation matrix for all chosen variables in the regression models, and as noted the highest correlation is between Debt/Asset and business risk around (0.521), on the other hand all the remaining variables do not have a high correlation with each other therefore the variables are proper for the panel regression analysis.

Table 2. Correlation matrix

\begin{tabular}{|c|c|c|c|c|c|c|}
\hline & Size & Tangibility & Business risk & $\mathrm{D} / \mathrm{A}$ & Institutional ownership & Marketability \\
\hline Size & 1.000 & & & & & \\
\hline Tangibility & -.2021 & 1.000 & & & & \\
\hline Business risk & -.0400 & -.0628 & 1.000 & & & \\
\hline $\mathrm{D} / \mathrm{A}$ & .1372 & -.0874 & .5219 & 1.000 & & \\
\hline Institutional ownership & .2389 & .0067 & -.0726 & .0033 & 1.000 & \\
\hline Marketability & -.0477 & -.0154 & -.0800 & -.3531 & .0476 & 1.000 \\
\hline
\end{tabular}

\subsection{Regression Results}

To test the hypothesis, the empirical data analysis had depended on panel data analysis for 82 Jordanian non-financial firms for the period from 2005-2013, the regression models consist of three models; pooled, fixed and random effect, and it is divided into two stages regarding the proxies of the dependent variable; the first one is Return on Assets (ROA), and then Return on Equity (ROE).

The panel regression models are as follows:

$$
\begin{aligned}
& R O A_{i t}=\beta_{0}+\beta_{1} \text { Size }_{i t}+\beta_{2} F T A_{i t}+\beta_{3} B R_{i t}+\beta_{4} D / A+\beta_{5} I O_{i t}+\beta_{6} M B+\varepsilon_{i t} \\
& R O E_{i t}=\beta_{0}+\beta_{1} \text { Size }_{i t}+\beta_{2} F T A_{i t}+\beta_{3} B R_{i t}+\beta_{4} D / A+\beta_{5} I O_{i t}+\beta_{6} M B+\varepsilon_{i t}
\end{aligned}
$$

The following tables presents all three panel regression models with dependent variables (ROA and ROE) respectively. Thus, in order to compare among these models to choose the appropriate one for our data, different tests are being used. First, Pooled model has a significant "F" statistic on 1\% significance level. Regarding the 
"T" statistic all the independent variables (size, business risk, debt/asset, institutional ownership, and marketability) were found statistically significant on $1 \%$ significance level; except for the tangibility it is insignificant.

The random effects model is significant according to "chi" ${ }^{2}$ " statistic at $1 \%$ significance level, it is also examined by the Breusch and pagan lagrangian multiplier (LM) and the null hypothesis (cross-sectional variance components are zero); and since the null hypothesis is rejected at $1 \%$ significance level, a panel effect is needed. This argument is in favor of the random effects model against the pooled data model. For the "Z" statistic the size, D/A, institutional ownership and marketability are significant at $10 \%$ significance level. For the tangibility and business risk they are insignificant.

Furthermore, to choose the convenient model among these models, a Hausman test will be employed. Since the "chi" statistic is significant at $1 \%$ significance level then the null hypothesis is rejected. This confirms the argument in favor of adopting the fixed model against the other models. In sum, the tests results confirm that the fixed effect model is superior to any other models in dealing with the available data.

Table 3. Panel regression output 1st model

\begin{tabular}{lllllll}
\hline ROA & Pooled & & Fixed & & Random \\
\hline Intercept & T-value & P-value & T-value & P-value & Z-value & P-value \\
Size & $-11.08^{* * *}$ & .000 & -1.37 & .171 & $-7.06^{* * *}$ & .000 \\
Tangibility & $11.08^{* * *}$ & .000 & $3.88^{* * *}$ & .000 & $7.64^{* * *}$ & .000 \\
Business risk & -0.94 & .348 & .67 & .501 & -.00 & .999 \\
D/A & $-4.57 * * *$ & .000 & $-4.06^{* * *}$ & .000 & -1.52 & .129 \\
Institutional ownership & $-3.34 * * *$ & .001 & $-8.26^{* * *}$ & .000 & $-6.64^{* * *}$ & .000 \\
Marketability & $2.80^{* * *}$ & .005 & .94 & .346 & $1.64^{*}$ & .100 \\
F-Test & $9.21^{* * *}$ & .000 & $5.73^{* * *}$ & .000 & $7.34^{* * *}$ & .000 \\
Chi ${ }^{2}$-Test & $60.88^{* * *}$ & .000 & $25.86^{* * *}$ & .000 & & .000 \\
\hline Lag Multiplier & & & & & $201.5^{* * *}$ & .000 \\
Hausamn test & $\mathbf{C h i}^{2}-\mathbf{T e s t}=$ & 228.9 & & $\mathbf{C h i}{ }^{2}-\mathrm{P}=$ & .000 & .000 \\
\hline
\end{tabular}

Note. $* * *$ Significant at $1 \%$ level, $* *$ significant at $10 \%$ level.

On the other hand, the following output was found when using ROE as the dependent variable. Pooled model has a significant "F" statistic at $1 \%$ significance level, regarding the " $\mathrm{t}$ " statistic all the independent variables were found statistically significant at $1 \%$ significance level which includes (size, business risk, debt/asset, and marketability), except for both tangibility and institutional ownership that were insignificant and hence we reject our main hypothesis.

Finally, both lagrangian multiplier (LM) and Hausman test are significant at (5\% and 1\%) respectively, for hausman fixed model is again in favor of other models, and LM is significant too which means that panel effect is needed.

Table 4. Panel regression output second model

\begin{tabular}{|c|c|c|c|c|c|c|}
\hline ROE & Pooled & & Fixed & & Random & \\
\hline & T-value & P-value & T-value & P-value & Z-value & P-value \\
\hline Intercept & $-7.70^{* * *}$ & .000 & -.48 & .633 & $-6.86^{* * *}$ & .000 \\
\hline Size & $8.02 * * *$ & .000 & $1.68^{* *}$ & .093 & $7.27 * * *$ & .000 \\
\hline Tangibility & -0.26 & .792 & .22 & .827 & -.22 & .828 \\
\hline Business risk & $-8.93 * * *$ & .000 & $-1.83^{* *}$ & .067 & $-7.57 * * *$ & .000 \\
\hline D/A & $-4.05 * * *$ & .000 & $-7.64 * * *$ & .000 & $-4.61 * * *$ & .000 \\
\hline Institutional ownership & 1.59 & .111 & .50 & .617 & 1.46 & .145 \\
\hline Marketability & $5.64 * * *$ & .000 & $3.00 * * *$ & .003 & $5.17 * * *$ & .000 \\
\hline F-Test & $57.72 * * *$ & .000 & $14.57 * * *$ & .000 & & \\
\hline Chi ${ }^{2}-$ Test & & & & & $281.8^{* * * *}$ & .000 \\
\hline Lag Multiplier & $\mathrm{Chi}^{2}-\mathrm{Test}=$ & 4.51 & & $\mathrm{Chi}^{2}-\mathrm{P}=$ & .016 & \\
\hline Hausamn test & $\mathrm{Chi}^{2}-\mathrm{Test}=$ & 40.00 & & $\mathrm{Chi}^{2}-\mathrm{P}=$ & .000 & \\
\hline
\end{tabular}

Note. *** Significant at $1 \%$ level, $* *$ significant at $10 \%$ level. 
Hence, our results show that there is no evidence of a relationship between institutional ownership and firm performance using data from Jordan. One explanation is that such investors are weak in Jordan and are not in a position to provide any monitoring services. This result contradicts the common evidence of the previous empirical work, in developed markets; that such result should be significant and positive. It also contradicts our main hypothesis. However, our result is in line with Sanchez and Garcia (2007), and Lee (2008) studies.

To double check the robustness of our findings, we use different robustness checks, including lagged regression modelling, between effects modelling, logit analysis (for profitable vs. non profitable firms). The results were not significantly different than what is reported in our paper and for parsimony; we did not report these models.

\section{Conclusions}

This part is for discussing the main findings of the panel data analysis output, to test the main hypothesis of the study whether there is a positive effect of institutional ownership on firm performance for 82 Jordanian non-financial firms during the period from 2005-2013.

According to the aforementioned tests, both models whether using ROA or ROE as dependent variable the most convenient model is the fixed effect regression. As a result, there is no strong evidence that there is a relationship between both the institutional ownership and firm performance for Jordanian listed firms, due to the insignificancy for "t" test, the study's hypothesis is rejected, and this is consistent with Sanchez and Garcia (2007), and Lee (2008) studies. This conclusion can be due to many reasons such as; the institutional ownership is a Double-edged sword; it has its own advantages and disadvantages. Therefore, their existence and influence could affect materially the types and risk level of investment decisions taken by the management which in return will affect the firm's performance as a whole. In addition to the above, Jordan is part of the Middle East countries so it is affected directly by unstable political conditions for several countries around us in the region especially after Arab spring, hence taking investment decisions becomes harder; and so that will affect the whole economic conditions, and so in return firms performance will be affected in a way or another.

For the explanatory variables added to the model; the positive relationship of tangibility is found statistically insignificant, as for the size and marketability both are found positively significant with firm performance. However, unlike the previous findings business risk and debt/asset are negatively significant with firm performance.

Our main results can be explained by the differences of the institutional framework of emerging markets, such as Jordan and other developed markets. Thus, we argue such investors have a weak role in firm monitoring. The study recommends that policy makers in Jordan need to develop a sound investment environment for institutional investors so they can act as a good governance tool. Consequently, this study can be considered as an attempt to investigate the debatable relationship between institutional investors and firm's performance, and hence there is a room for further studies to include ownership structure factors, as well as cross country analysis using emerging markets that would in return increase our knowledge in the relationship between various components of ownership structure and the firm's performance.

\section{References}

Belkhir, M. (2004). Board Structure, Ownership Structure and Firm Performance: Evidence from Banking. Applied Financial Economics, 19(19), 1581-1593. http://dx.doi.org/10.1080/09603100902967561

Berle, A., \& Means, G. (1932). The Modern Corporation and Private Property. New York: Macmillan, Harcourt, Brace, and World.

Bhattacharya, P., \& Graham, M. (2007). Institutional Ownership and Firm Performance: Evidence from Finland. School working paper, Faculty of Business and Law, School of Accounting, Economics and Finance, Accounting finance series. http://dx.doi.org/10.2139/ssrn.1000092

Bjuggren, P., Eklund, J., \& Wiberg, D. (2007). Institutional Owners and Firm Performance: The Impact of Ownership Categories on Investments. Centre of Excellence for Science and Innovation Studies (CESIS) Electronic Working Paper Series. http://dx.doi.org/10.2139/ssrn.967638

Brickley, J. A., Lease, R. C., \& Smith, C. W. (1988). Ownership structure and voting on anti-takeover $\begin{array}{lllll}\text { amendments. Journal of Financial } & \text { Economics, }\end{array}$ http://dx.doi.org/10.1016/0304-405X(88)90047-5

Chen, J., Blenman, L., \& Chen, D. (2008). Does institutional ownership create values? New Zealand case. Quarterly Journal of Finance and Accounting, 47(4), 109-132.

Cornett, M., Marcus, A., Saunders, A., \& Tehranian, H. (2007). The impact of institutional ownership on 
corporate operating performance. Journal of Banking \& Finance, 31, 1771-1794. http://dx.doi.org/10.1016/j.jbankfin.2006.08.006

Davis, P., \& Steil, B. (2001). Institutional Investors. Journal of International Review of Economics \& Finance, 12(1), 145-147.

Del Guercio, D., \& Hawkins, J. (1999). The motivation and impact of pension fund activism. Journal of Financial Economics, 52, 293-340. http://dx.doi.org/10.1016/S0304-405X(99)00011-2

Demsetz, H. (1983). The Structure of Ownership and the theory of the Firm. The Journal of Law and Economics, 26(2), 375-390. http://dx.doi.org/10.1086/467041

Demsetz, H., \& Lehn, K. (1985). The Structure of Corporate Ownership: Causes and Consequences. Journal of Political Economy, 93(6), 1155-1177. http://dx.doi.org/10.1086/261354

Demsetz, H., \& Villalonga, B. (2001). Ownership structure and corporate performance. Journal of Corporate Finance, 7, 209-233. http://dx.doi.org/10.1016/S0929-1199(01)00020-7

Fauzi, F., \& Locke, S. (2012). BOARD STRUCTURE, Ownership Structure and firm Performance: A study of NEW ZEALAND listed-firms. Asian Academy of Management Journal of Accounting and Finance (AAMJAF), 8(2), 43-67.

Fazlzadeh, A., Hendi, A., \& Mahboubi, K. (2011). The Examination of the Effect of Ownership Structure on firm Performance in listed firms of Tehran Stock Exchange based on the Type of the industry. International Journal of Business and Management, 6(3), 249-266. http://dx.doi.org/10.5539/ijbm.v6n3p249

Federal Reserve Financial Economists Roundtable. (1998). Statement on Institutional Investors and Corporate Governance, Dec 1, 1998.

Gilson, R., \& Roe, M. (1993). Understanding the Japanese keiretsu: Overlaps between corporate governance and industrial organization. Yale Law Journal, 102, 871-906. http://dx.doi.org/10.2307/796835

Grossman, S., \& Hart, O. (1980). Takeover bids, the free rider problem, and the theory of the corporation. Bell Journal of Economics, 11, 42-64. http://dx.doi.org/10.2307/3003400

Hartzell, J., \& Starks, L. (2003). Institutional investors and executive compensation. The Journal of Finance, 58(6), 2351-2374. http://dx.doi.org/10.1046/j.1540-6261.2003.00608.x

Healy, J. (2003). Corporate governance \& shareholder value: Challenges facing New Zealand. Palmerton North: Dunmore.

Hu, Y., \& Izumida, S. H. (2008). The Relationship between Ownership and Performance: A Review of Theory and Evidence. International Business Research, 1(4), $72-78$.

Jensen, M. C., \& Meckling, W. H. (1976). Theory of the Firm: Managerial Behaviour, Agency Costs and $\begin{array}{llll}\text { Ownership Structure. Journal of Financial Economics, 4, 305-360. } & \text { 4, }\end{array}$ http://dx.doi.org/10.1016/0304-405X(76)90026-X

Joher, H., Ali, M., \& Nazul. (2006). The Impact of Ownership Structure on Corporate Debt Policy two stage least square simultaneous model approach for post crisis period evidence from Kwala Lumpur stock exchange. International business and economics research Journal, 5(5), 51-63.

Kochhar, R., \& David, P. (1996). Institutional investors and firm innovation: A test of competing hypotheses. $\begin{array}{lllll}\text { Strategic } & \text { Management } & \text { Journal, } & \text { 73-84. }\end{array}$ http://dx.doi.org/10.1002/(SICI)1097-0266(199601)17:1<73::AID-SMJ795>3.0.CO;2-N

La Porta, R., Lopez-De-Silanes, F., \& Shleifer, A. (1999). Corporate ownership around the world. Journal of Finance, 54, 471-518. http://dx.doi.org/10.1111/0022-1082.00115

Lee, S. (2008). Ownership Structure and Financial Performance: Evidence from Panel Data of South Korea. University of Utah, Department of Economics, Working Paper No.17.

Maug, E. (1998). Large shareholders as monitors: Is there a trade-off between liquidity and control? Journal of Finance, 53, 65-98. http://dx.doi.org/10.1111/0022-1082.35053

McConnell, J. J., \& Servaes, H. (1990). Additional evidence on equity ownership and corporate value. Journal of Financial Economics, 27, 595-612. http://dx.doi.org/10.1016/0304-405X(90)90069-C

Nesbitt, S. (1994). Long-Term Rewards from Shareholder Activism: A Study of the CalPERS Effect. Journal of Applied Corporate Finance, 75-80. http://dx.doi.org/10.1111/j.1745-6622.1994.tb00251.x 
Pound, J. (1988). Proxy contests and the efficiency of shareholder oversight. Journal of Financial Economics, 20, 237-265. http://dx.doi.org/10.1016/0304-405X(88)90046-3

Roe, M. (1994). Strong mangers, weak owners: The political roots of American corporate finance. Princeton, NJ: Princeton University Press.

Sanchez-Ballesta, J., \& Garcia-Meca, E. (2007). A Meta analytic Vision of the Effect of Ownership Structure on Firm Performance. Corporate $\quad$ Governance, $15,893$. http://dx.doi.org/10.1111/j.1467-8683.2007.00604.x

Shleifer, A., \& Vishny, R. (1997). A survey of corporate Governance. The Journal of Finance, LII(2). http://dx.doi.org/10.1111/j.1540-6261.1997.tb04820.x

Shleifer, A., \& Vishny, R. (1986). Large shareholders and corporate control. Journal of Political Economy, 94, 448-461. http://dx.doi.org/10.1086/261385

Wellalage, N. H., \& Locke, S. (2012). Ownership structure and firm financial performance: Evidence from panel data in Sri Lanka. Journal of Business Systems, Governance \& Ethics, 7(1), 52-65.

\section{Copyrights}

Copyright for this article is retained by the author(s), with first publication rights granted to the journal.

This is an open-access article distributed under the terms and conditions of the Creative Commons Attribution license (http://creativecommons.org/licenses/by/3.0/). 